\title{
PEMBUATAN KOLAM TERPAL UNTUK BUDI DAYA IKAN LELE DI PONDOK PESANTREN AT-THOHIRIYAH, TERPATIH GALAK SLAHUNG KABUPATEN PONOROGO
}

\author{
Satworo Adiwidodo ${ }^{1}$, Imam Mashudi ${ }^{2}$, Utsman Syah Amrullah ${ }^{3}$, R.N. Akhsanu Takwim ${ }^{4}$, \\ Moh. Hartono ${ }^{5}$ \\ 1,2,3,4,5 Politeknik Negeri Malang
}

\begin{abstract}
Abstrak
Pondok Pesantren At Thoiriyah adalah pondok yang mengasuh kegiatan madrasah dinniyah dan tafidz Qur'an. Selain bekal agama yang mumpuni, pondok pesantren juga berusaha untuk membekali santri/santriwatinya dengan kemampuan untuk bisa mandiri di masyarakat dengan kemampuan pertanian, peternakan, pertukangan dan lain sebagainya. Santri/santriwati perlu dirangsang untuk belajar mandiri atau diajari melalui proses bimbingan untuk berperan aktif sebagai subyek pembangunan masyarakat. Sejalan dengan pemikiran di atas, diusulkan suatu kegiatan pemberdayaan masyarakat yaitu pelatihan dan pembuatan kolam terpal untuk budi daya ikan Lele di di Pondok Pesantren At-Thohiriyah, Terpatih Galak Slahung, Kabupaten Ponorogo. Kegiatan ini dirintis sebagai usaha untuk membangkitkan minat santri/santriwati untuk memulai usaha berdasarkan potensi usaha yang ada di lingkungan sekitar.

Hasil dari kegiatan ini adalah berupa 1 buah kolam terpal bulat dengan diameter $3 \mathrm{~m}$ dengan kedalaman $1 \mathrm{~m}$ dengan rangka wiremesh dengan alas terpal dan seperangkat modal awal untuk memulai usaha budidaya lele berupa benih dan pakan lele serta modul pelatihan.
\end{abstract}

Kata kunci-kolam ikan portable, kolam terpal, ikan lele, modul pelatihan

\section{PENDAHULUAN}

\subsection{Analisis Situasi}

Pondok Pesantren At Thoiriyah terletak di Desa Terpatih Kecamatan Galak Slahung, Kabupaten Ponorogo, Jawa Timur. Pondok Pesantren ini didirikan tahun 2008 oleh KH. Nur Thohir. Pondok Pesantren At Tohiriyah berdiri diatas lahan seluas kurang lebih 2 hektare yang dibagi atas pondok putra dan pondok putri. Saat ini, Pesantren At Thoiriyah memiliki jumlah santri 61 dan 26 santriwati dengan jumlah ustsz/ustadzah 14 orang. Kegiatan yang diasuh pondok meliputi kegiatan madrasah dinniyah dan tafidz Qur'an.

Selain bekal agama yang mumpuni, pondok pesantren juga berusaha untuk membekali santri/santriwatinya dengan kemampuan untuk bisa mandiri di masyarakat dengan kemampuan pertanian, peternakan, pertukangan dan lain sebagainya.
Santri/santriwati perlu dirangsang untuk belajar mandiri atau diajari melalui proses bimbingan untuk berperan aktif sebagai subyek pembangunan masyarakat. Di sektor inilah peran penting Perguruan Tinggi diharapkan. Perguruan tinggi mempunyai sumber daya manusia yang berkualifikasi akademik yang tinggi dengan pengalaman penenetian yang mumpuni ditambah bahwa Perguruan Tinggi memiliki sarana dan prasarana yang memadahi, sebagai perwujudan dari Tri Dharma, maka Perguruan Tinggi mempunyai keharusan untuk berperak aktif dalam proses pemberdayaan masyarakat untuk membentuk masyarakat yang masju, adil, dan makmur.

Sejalan dengan pemikiran di atas, diusulkan suatu kegiatan pemberdayaan masyarakat yaitu pelatihan dan pembuatan kolam terpal untuk budi daya ikan Lele di di Pondok Pesantren At- Thohiriyah, Terpatih 
Galak Slahung, Kabupaten Ponorogo. Kegiatan ini dirintis sebagai usaha untuk membangkitkan minat santri/santriwati untuk memulai usaha berdasarkan potensi usaha yang ada di lingkungan sekitar. Potensi yang ada berupa tersedianya waktu yang banyak, lahan yang luas, cukupnya sumber tenaga manusia serta sumber air tanah yang sebagai peluang usaha tambahan untuk meningkatkan perekonomian santri/santriwati.

\subsection{Perumusan Masalah}

Dengan latar belakang sebagaimana telah diuraikan di atas, maka dapat dirumuskan permasalahan sebagai berikut:

a. Bagaimana merencana kolam terpal yang cocok untuk usaha awal budidaya ikan Lele di Pondok Pesantren At Thohiriyah Terpatih Galak Slahung Ponorogo

b. Bagaimana membuat kolam terpal yang cocok untuk usaha awal budidaya ikan Lele di Pondok Pesantren At Thohiriyah Terpatih Galak Slahung Ponorogo

c. Bagaimana melakukan budidaya ikan Lele di kolam terpal di Pondok Pesantren At Thohiriyah Terpatih Galak Slahung Ponorogo

\section{TINJAUAN PUSTAKA}

\subsection{Budidaya Lele}

Komoditas perikanan darat yang dapat membantu menanggulangi masalah gizi terutama dalam hal pembentukan protein hewani dapat tercukupi adalah ikan lele. Permintaan lele di negara kita semakin meningkat sejalan dengan populernya ikan lele sebagai hidangan yang sangat lezat.

Aspek Sosial, komoditas hasil budidaya ikan lele dapat diterima oleh masyarakat luas dan dapat diterima oleh berbagai lapisan masyarakat. Artinya tidak ada masyarakat yang mengkultuskan lele atau tidak adanya pantangan dari masyarakat luas. Sehingga siapa saja bisa membudidayakan lele, baik dalam skala kecil, menengah ataupun skala yang besar. Proses produksi tidak menghasilkan limbah yang memberikan dampak negatif kepada masyarakat dan lingkungan.

Aspek Ekonomi, budidaya lele dapat dilakukan oleh setiap orang dengan modal yang sedikit dan tidak rumit sehingga dapat dilakukan dalam skala rumah tangga. Hasil dari budidaya ikan dapat dikonsumsi sendiri sebagai pemenuhan gizi keluarga dan hasil lebihnya dapat dijual sebagai tambahan pendapatan keluarga

Secara teknis, budidaya lele merupkan budidaya yang tidak terlalu sulit dan rumit. Orang awam kebanyakan bisa melakukan budidaya asalkan memiliki kemauan dan ketelatenan, untuk merawat dan memonitor tumbuh kembang bibit ikan lele. Ikan lele merupakan salah satu jenis ikan yang sanggup hidup dalam kepadatan tinggi. Ikan ini memiliki tingkat konversi pakan menjadi bobot tubuh yang baik. Dengan sifat seperti ini, budidaya ikan lele akan sangat menguntungkan bila dilakukan secara intensif. Terdapat dua segmen usaha budidaya ikan lele, yaitu segmen pembenihan dan segmen pembesaran. Segmen pembenihan bertujuan untuk menghasilkan benih ikan lele, sedangkan segmen pembesaran bertujuan untuk menghasilkan ikan lele siap konsumsi.

\subsection{Penyiapan Kolam Tempat Budidaya Lele}

Ada berbagai macam tipe kolam yang bisa digunakan untuk tempat budidaya ikan lele. Setiap tipe kolam memiliki keunggulan dan kelemahan masing-masing bila ditinjau dari segi usaha budidaya. Untuk memutuskan kolam apa yang cocok, harap mempertimbangkan kondisi lingkungan, ketersediaan tenaga kerja dan sumber dana ada.

Tipe-tipe kolam yang umum digunakan dalam budidaya ikan lele adalah kolam tanah, kolam semen, kolam terpal, jaring apung dan keramba.

\subsection{Kolam Terpal Bulat}

Kolam ikan jenis terpal ini merupakan pengembangan dari jenis kolam permanen. Dimana kolam ikan dapat dipindahkan, dapat menyesuaikan dengan luas lahan yang tersedia dan dapat dilipat seandainya tidak dipakai lagi. Kolam ikan terpal adalah kolam ikan yang dibuat menggunakan konstruksi besi dan menggunakan terpal sebagai wadah airnya. Kolam ini bersifat portable karena dapat dipindah dan disesuaikan dengan lahan yang ada. Kolam jenis ini memiliki keunggulan mudah dibuat, ringan, bentuk dan ukuran bisa disesuakan dengan tempatnya, dan dapat 
dipindahkan ketempat lain dengan relatif mudah.

Langkah untuk membuat kolam portable ini adalah sebagai berikut:

1. Memilih lokasi/lahan

2. Membuat rangka besi

3. Memasang terpal

4. Mengatur instalasi air (pembuangan dsb.)

\section{METODE}

Metode yang akan dilakukan dalam kegiatan PKM ini antara lain:

1. Survey lapangan untuk mempelajari permasalahan yang ada dan selanjutnya memberikan penawaran tentang Pelatihan dan Pembuatan Kolam Terpal untuk Budi Daya Ikan Lele di Pondok Pesantren AtThohiriyah, Terpatih Galak Slahung, Kabupaten Ponorogo

2. Kegiatan berikutnya adalah penyusunan proposal kegiatan yang diusulkan kepada Unit Pelaksana Teknis P2M Politeknik Negeri Malang.

3. Setelah mendapat persetujuan, dilaksanaan kegiatan pelatihan pengelasan dengan produk tiang penyangga lampu penerangan jalan

\section{HASIL DAN PEMBAHASAN}

Kegiatan PKM diawali dengan pertemuan bersama pengasuh ponpes At Thohiriyah Terpatih Galak Slahung Ponorogo membahas pemberdayaan pondok untuk meningkatkan ketahanan pangan. Dari pertemuan disepakati dibuat kolam untuk bididaya lele. Selain untuk melatih santri/santriwati dalam hal keahlian budidaya lele juga bisa dijadikan sumber pendapatan pondok.

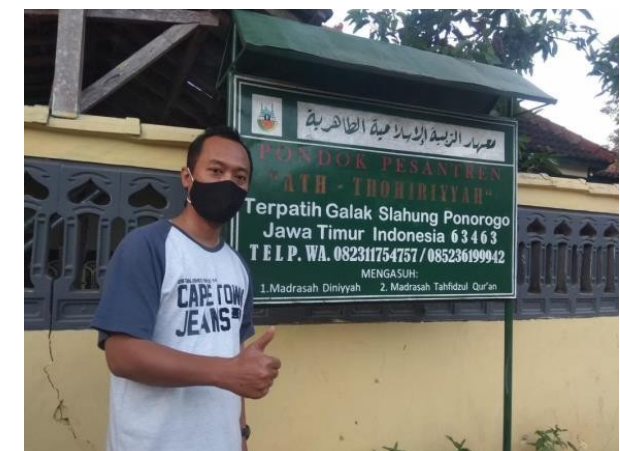

Gambar 1. Survey tim pengabdian ke Ponpes At-Thohiriyah

\subsection{Penyiapan Lahan}

Sebelum dibuat kolam lele, langkah pertama adalah penyiapan lahan. Lahan yang dibutuhkan haruslah rata dan bebas dari batubatuan untuk meningkatkan umur pakai kolam. Lahan tersebut harus cukup luas sesuai dengan ukuran kolam yang akan dibuat. Lahan yang digunakan untuk kolam sebaiknya cukup terlindung agar air kolam tidak terlalu panas agar benih lele yang nantinya disebar tidak mudah mati.

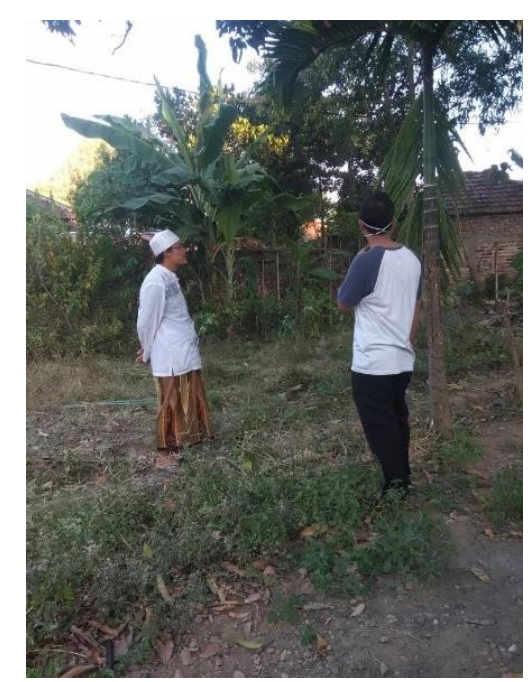

Gambar 2. Survei lokasi pembuatan kolam dengan pengasuh ponpes

Setelah lahan yang akan dijadikan kolam telah disepakati, maka langkah berikutnya adalah pembersihan dan perataan lahan. Hal ini sangat penting untuk memastikan dasar kolam rata agar kolam tidak miring, sehingga kontruksi rangka kokoh dan awet. Pembersihan lahan juga dimaksudkan untuk mencegah adanya batu yang bisa merobek terpal pada dasar kolam, khususnya pada saat proses panen lele nantinya. 


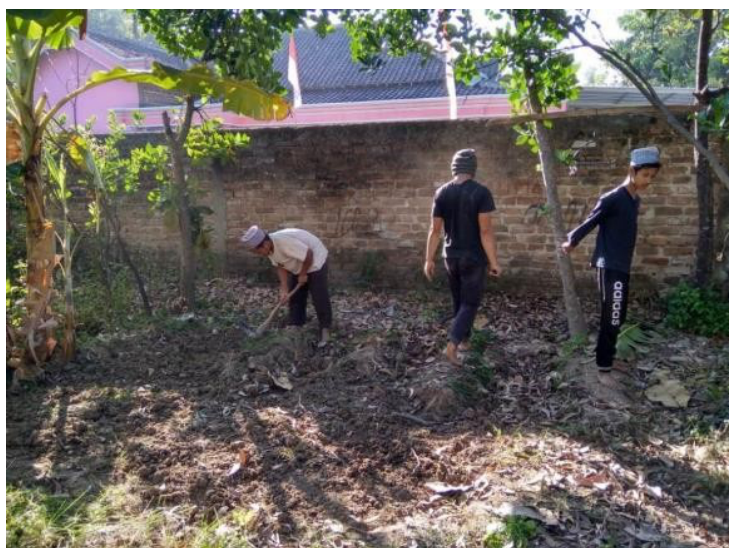

Gambar 3. Perataan tanah oleh santi ponpes

\subsection{Pembuatan Kolam Terpal}

Penggunaan wire-mesh untuk rangka kolam terpal dapat mempercepat pengerjaan dan memangkas biaya produksi dan juga meningkatkan umur pakai kolam.

Alat dan bahan yang harus disiapkan dalam pembuatan kolam bundar:

1. Kolam Bulat (Bahan Terpal atau Terpoly)

2. Besi Wire-mesh, minimal ukuran $7 \mathrm{~mm}$, untuk kolam bulat dengan diameter 3 meter kebawah, cukup 1 buah Wire-mesh dengan panjang 5,4-meter dan lebar 2,1 meter

3. Bengkokan (knee) paralon 2 buah

4. Paralon (panjang dan besar sesuaikan)

5. Kabel Ties / Tierap / Ripet

6. Terpal Atap (Talang) (panjang dan besar sesuaikan)

7. Las

8. Cat

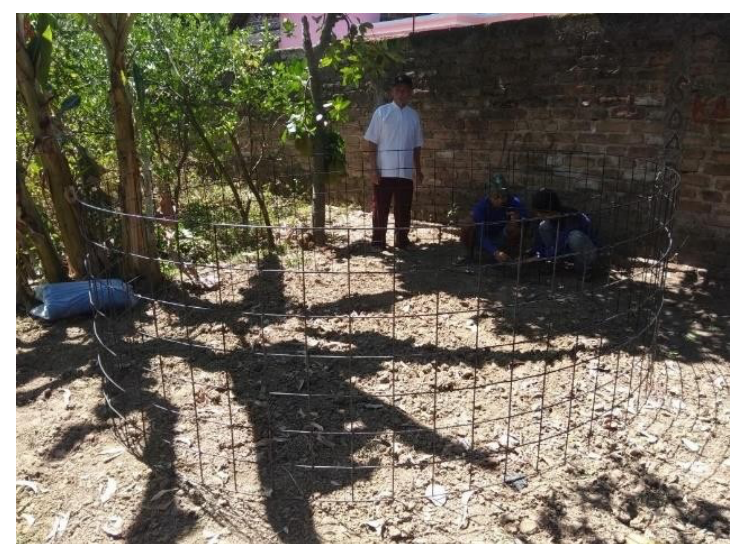

Gambar 4. Rangka wiremesh di atur sesuai ukuran kolam $(d=3 m)$

Wiremesh yang telah disiapkan dipasang sesuai desain ukuran yang telah disiapkan. Memastikan bentuk kontuksi rangka bundar dan tidak lonjong. Setelah rangka wiremesh terbentuk, pasangkan pelindung pada tepi wiremesh untuk mencegah robek terpal ketika terkena tepi wiremesh yang tajam.

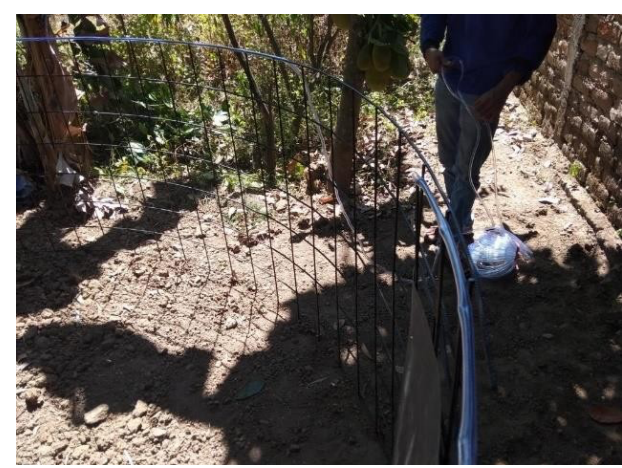

Gambar 5. Pemasangan pelindung wiremesh

Sisi samping dalam rangka wiremesh dipasangi dengan terpal talang. Fungsi terpal talang ini juga sebagai pelindung terpal dari rangka wiremesh yang tajam.

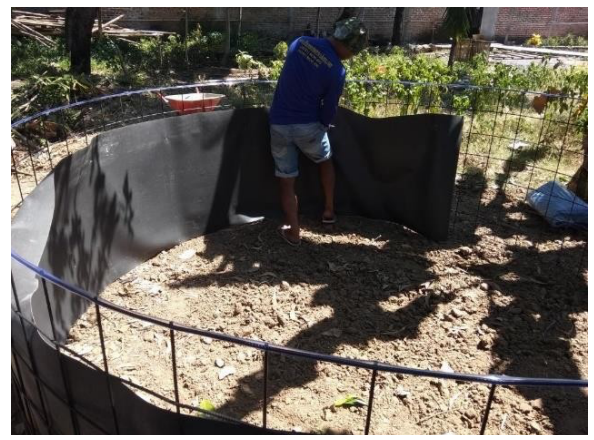

Gambar 6. Pemasangan terpal talang

Langkah berikutnya adalah mengisi dan meratakan dasar kolam dengan pasir sungai yang halus. Pastikan bahwa pasir yang digunakan bebas dari kerikil atau batu koral.

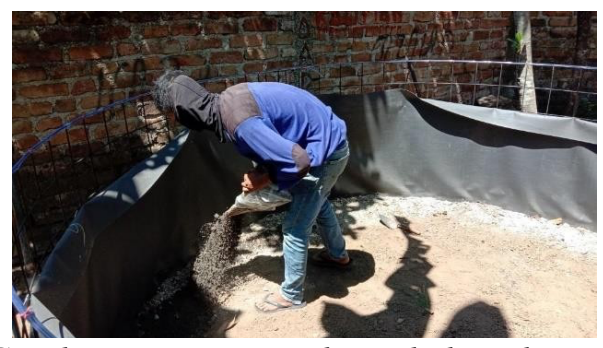

Gambar 7. Perataan dasar kolam dengan pasir 


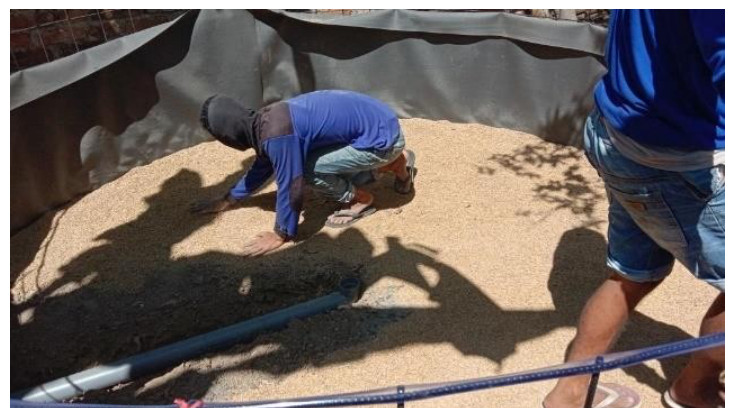

Gambar 8. Pelapisan dasar kolam dengan sekam padi

Diatas pasir yang telah rata, diletakkan sekam padi untuk memastikan dasar kolam rata dan lunak sebelum dipasangi dengan terpal. Tujuannya sekali lagi adalah untuk melindungi terpal kolam agar tidak mudah rusak dan tahan lama. Dengan penanganan yang tepat, umur pakai kolam bisa mencapai 5 tahun. Pastikan juga pada dasar kolam dibuat saluran untuk pembuangan dan air kolam baik untuk proses manajemen air maupun pada saat pembuangan pada saat akan panen. Untuk memudahkan air pembuangan mengalir keluar, pastikan permukaan dasar kolam agak cekung di tengah.

Setelah dasar kolam benar-benar rata dan lunak, maka terpal bisa di pasang dan dirapikan. Buaat lubang pada tengah terpal dan sambungkan dengan kne kemudian di klem agar tidak bocor. Pada atas lubang pembuangan dipasangi filter untuk menjaga agar benih tidak terikut keluar saat dilakukan penggantian air.

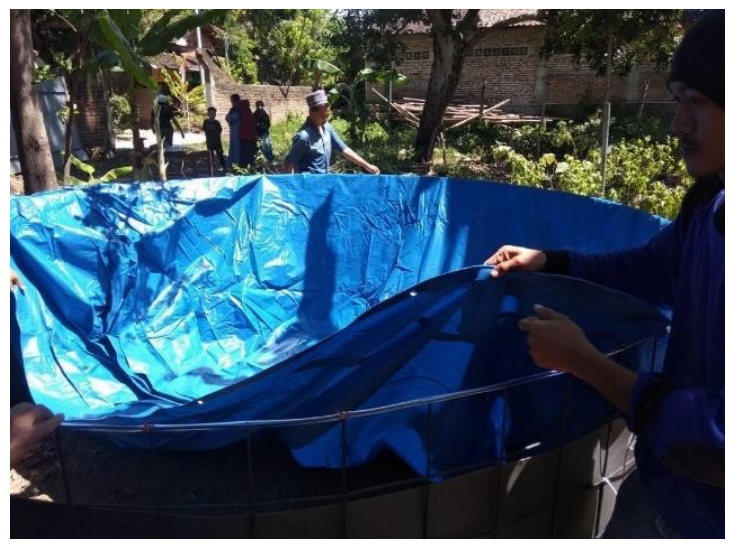

Gambar 9. Proses pemasangan terpal

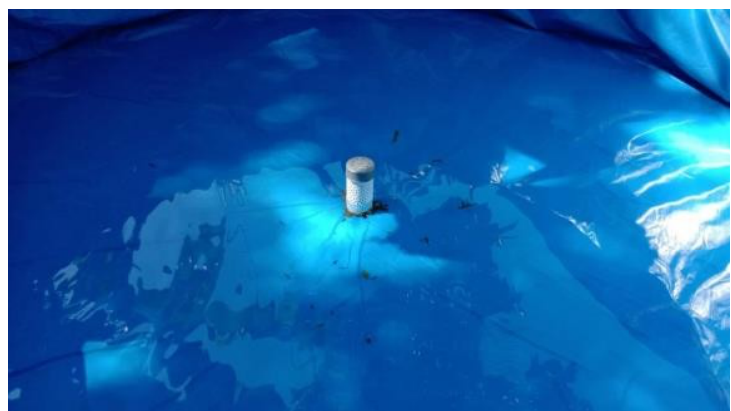

Gambar 10. Filter dan saluran pembuangan

Setelah saluran buang selesai dibuat, langkah terakhir adalah merapikan posisi terpal agar sesuai dengan bentuk rangkanya. Untuk mempertahankan posisi terpal, ikatkan terpal pada lubang mata ikan terpal dengan rangka menggunakan tali tampar plastik ukuran $0,5 \mathrm{~cm}$. Pastikan tali mengikat secara rapi dan kuat pada rangka wiremesh. Dengan demikian maka proses pembuatan kolam terpal bulat sudah selesai.

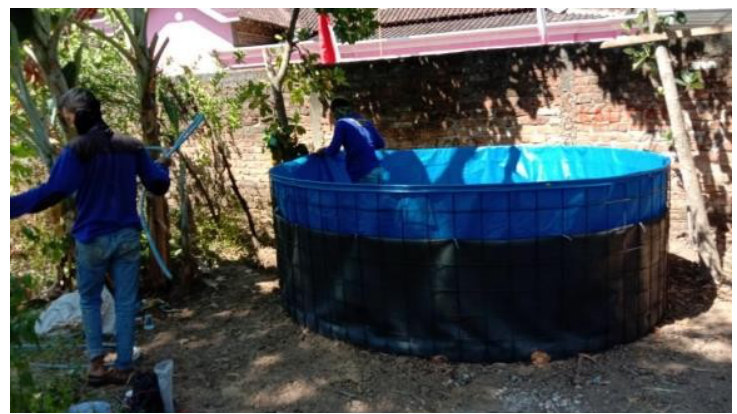

Gambar 11. Proses terpal pada rangka

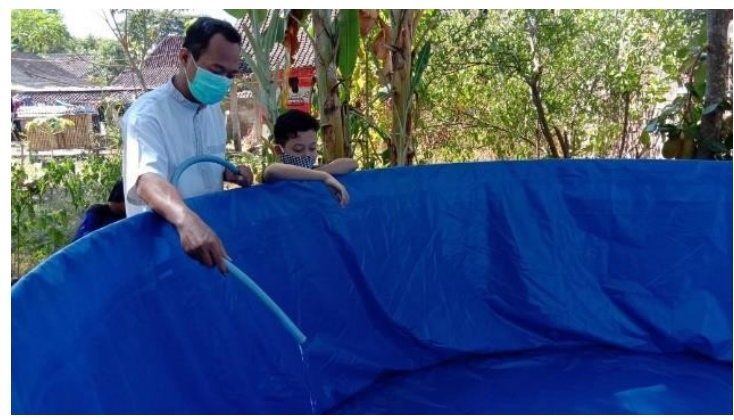

Gambar 12. Proses pengisian air

Setelah kolam selesai dibuat, maka diisi dengan air kira-kira $50 \mathrm{~cm}$. Air isian pertama bisa dibuang dalam 1 hari. Hal ini dimaksudkan untuk membuang zat-zat kimia pada permukaan terpal agar benih yang disebar nantinya bisa bertahan dan sehat. Setelah air isian pertama dibuang, isi kembali kolam setinggi sekitar $80 \mathrm{~cm}$. Biarkan selama 
1-2 minggu sehingga air kolam agak kehijauhijauan karena lumut baru bisa melaksanakan tebar benih.

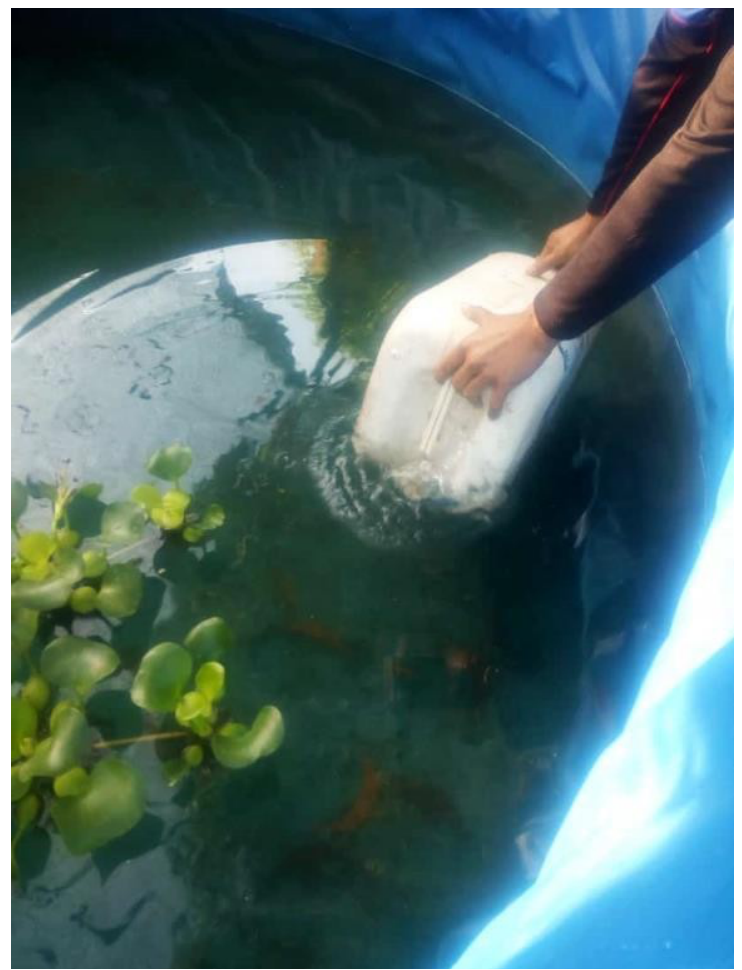

Gambar 13. Penebaran benih lele setelah kolam di isi air selama 2 minggu

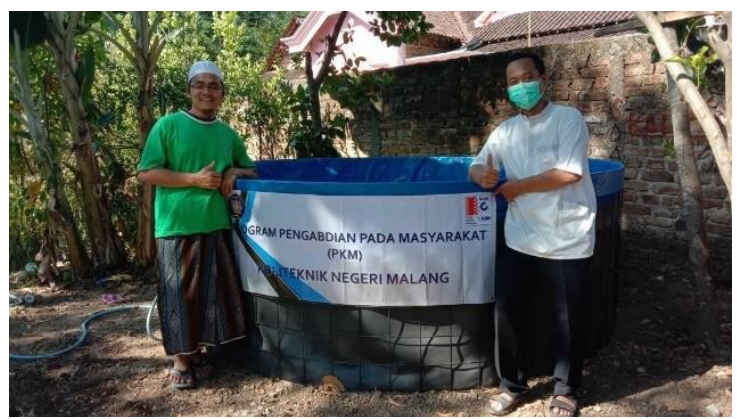

Gambar 14. Penyerahan kolam terpal bulat diameter 3 meter pada pengasuh pondok

\section{SIMPULAN DAN SARAN}

\subsection{Simpulan}

Simpulan yang dapat diambil dari kegiatan pengabdian pada masyarakat ini adalah:

1. kolam terpal bulat dapat digunakan untuk budidaya ikan lele memanfaatkan lahan sempit di Pondok Pesantren At Thohiriyah Terpatih Galak Slahung Ponorogo

2. Tahapan pembuatan kolam terpal bulat adalah, perataan lahan, pemasangan rangka wiremesh, pembuatan saluran pembuangan dan pemasangan terpal.

3. Budi daya lele pada kolam terpal bulat bisa dimulai 1-2 minggu setelah setelah pengisian air yang kedua.

\subsection{Saran}

Pada kegiatan Pengabdian Kepada Masyarakat (PKM) berikutnya bisa diusulkan untuk dilaksanakan pengembangan budidaya lele dengan sitem biofloc untuk meningkatkan produksi dan faktor ekonomis. Beberapa hal yang terkait dengan budidaya lele yang perlu diperhatikan:

1. Kapasitas kolam dan jumlah bibit lele harus benar-benar diperhitungkan dengan tepat agar populasi tidak terlalu padat atau terlalu longgar

2. Penggantian air perlu secara rutin dilakukan untuk menjaga kesehatan lele dan kebersihan kolam.

3. Pemisahan lele yang memiliki ukuran seragam harus sering dilakukan, agar tidak terjadi kesenjangan ukuran yang berlebih. Menyebabkan tidak meratanya pakan.

4. Pelaksanaan PKM ini dalam masa pandemi covid 19, maka dalam pelaksanaannya harus tetap memperhatikan protokol kesehatan.

\section{DAFTAR PUSTAKA}

[1] http://alamtani.com/budidaya-ikanlele.html

[2] http://www.infoagribisnis.com/2015 /06/cara- ternak-lele

[3] https://gdmorganic.com/panduanbudidaya- ikan-lele

[4] https://konstruksikolamterpal.net/car a-ternak- lele

[5] Untung Hasan Lutfi, Sukses budidaya lele Sangkuriang kolam bundar sistem bio floc, ppt, Politeknik Agroindustri Sang Hyang Seri

[6] Tri Rachmawati, Teknik budidaya (pembesaran) ikan lele di kolam terpal, ppt, DKP Kab. Bangka 